\title{
The Role of Islamic Ethics in Accounting Environment
}

\author{
${ }^{1}$ Dr. Farooq Salman Alani, ${ }^{2}$ Dr. Haris Kareem Alani \\ ${ }^{I}$ (Accounting and Finance programme/ FBEPS, UBD) \\ ${ }_{2}^{2}$ (Accounting Dept. Business \&finance/ Gulf University, Bahrain)
}

\begin{abstract}
Accounting organizations continue to develop various forms of moral laws in order to maintain its reputation and credibility and thus support the pillars of those organizations in the market. There have been Islamic accounting organizations that depend on the foundations ofIslamic lawethics as well as the traditional pillars. These institutions have emerged to give new momentum accounting environment to get the best results that enhance the confidence of individuals and organizations working. This harmony between the goals has led to the framing of accounting environment at the application level frameworks and powerful sound that will address all the bottlenecks and respond to faults that may occur in the application of Accounting.
\end{abstract}

\section{Introduction}

Enron, WorldCom and Arthur Andersen - all have one thing in common. They were famous for the wrong reason. They were involved in unethical accounting practices which soon made them household names. This goes to show the importance of ethics in today's world. In a company, the main role of an accountant is to prepare the financial statements for the Board of Director's, shareholders and stakeholders. In the preparation, they have to ensure that information is obtained in a good manner and laid out to show the true state of the organisation. They have to learn to report on an 'as is' basis and not 'as ought to be' basis.

For an Islamic accountant, there is an extra rule to follow; they have to always comply with the Shari'a teachings. Thus, they are not only accountable to the Board of Directors but also will be held accountable in the HereAfter if they are negligence of their duty. This report discusses the code of ethics for accountants as perceived in both conventional and Islamic view.

The layout of the paper is as follows: the introduction section comprises of problem statement, research questions and objectives. Following that is the literature review, methodology, findings, conclusion and some recommendations, for handling the problem as well as for future research.

\section{Problem statement}

In today's world, moral or ethical values are highly looked upon in one's self because it reflects their true nature. They are good values needed to be present in an employee which ensures a smooth flow in any process. However, the ever presence of temptations has the power to weaken ones ethical judgments, in all professions alike. Even so, at times, the punishments outweigh the mistake and hence, end up paying a lot than what one bargained for.

Being an accountant, this is no exception. One can think of many ways of 'bending' the rules and end with a bad reputation. And reputation is not something built in five minutes. Ethics or moral values are outlined in management of businesses but one forgets it as they make millions. The values are changed now to accommodate for what they think is morality. And, unfortunately, due to this, a lot of accounting malpractice cases can be heard of nowadays. The Enron scandal, followed by the collapse of Arthur Andersen is just an example of how great the problem has become. Accountants are more inclined towards turning a blind eye to the most obvious of mistakes. This raises the question, why are accountants becoming unethical? Is the code of ethics not strict enough or are they simply ignoring it? Are they aware of their accountability towards the organisation and the stakeholders alike?

\section{Research question}

Whether it is being an accountant or studying to be one, one's morality is always tested, either in the form of real-life scenarios or case-study questions in an exam paper. To achieve the purpose of this research, the following questions are taken into account:

i. Are there any ethical codes of conduct for an accountant? If so, how is it practiced?

ii. Is there any difference between the ethical values of an Islamic and traditional accountant?

\section{Objectives of research}

The main objective of the research is to look into the ethical values present in both a traditional and Islamic accountant. Specifically, the aims are:

i. To recognise the importance of ethics in an accountant 
ii. To enable a better understanding on ethics, as practiced by both the Islamic and traditional accounting

iii. To explain the difference, if any, between the ethical values practiced in Islamic and a traditional accounting

\section{Literature Review}

This part of the paper will look into some of the previous research on the said topic. It is divided into two sub-headings: ethics and accountability and ethics and education.

\subsection{Ethics and accountability}

Accountability can be defined as 'the fact or condition of being accountable', whereby accountable means 'required or expected to justify actions or decisions' or simply 'responsibility'. In the accounting profession, the main objective is to aid accountability (Lewis, 2006). Being accountable in the Islamic sense refers to the answerability of an individual to Allah in all his undertakings in this world. This brings about the notion of trustee (khalifah or vicegerent) where everything in this world is provided by Allah for the mankind and hence, it becomes their responsibility to gain its benefits. Regarding trust, it is stated in Al-Qur'an:

'O you who believe! Betray not Allah and His Messenger, nor betray knowingly your Amanat (things entrusted to you, and all the duties which Allah has ordained for you).'(Surah Al-Anfal, 8:27)

Being accountable is an ethical value which not only brings benefit to an individual but the society as a whole. When an individual has performed his duties, the effect of it is passed on to the society. Hence, if a duty is performed in a good manner, then the society enjoys it as well and vice versa.

The notion that self-interest prevails over one's ethical judgement is not new. One of the surveys conducted shows self-interest as one of the main factors of ethical failures (Jackling, Cooper, Leung, \& Dellaportas, 2007). Other factors which could affect morality are absence of independence, lack of ethical sensitivity and failure to maintain objectivity. In another survey conducted to identify if the love of money could actually affect an ethical judgement, it was found that it only affected illegal activities and not questionable acts (Elias \& Farag, 2010).

\subsection{Ethics and education}

Throughout any accounting courses, it is complimentary if some form of ethical modules were made compulsory for the students. Why this is so? As is known to all, education gives knowledge to an individual. Therefore, to produce an ethical accountant, the education has to be provided for morality to be inculcated within an individual.

This is what Huss and Patterson (1993) also noted in their paper 'Ethics in Accounting: Values education without Indoctrination'. As highlighted in their paper, there are seven objectives to be fulfilled when ethics and accounting are integrated: relate the accounting with the ethical issues, recognise issues with ethical implications in accounting, develop a sense of responsibility, develop the abilities needed to deal with ethical dilemmas, learn to deal with uncertainties, ability to alter ethical behaviour and understand the relationship of accounting ethics with the general ethics field. Furthermore, academicians should only present the ethical dilemmas to students and allow them to come up with their own potential solution. They should not coerce students with their own solutions. When different ideas are brought forward from different students, there is a lot of room for improvement to make better ethical decision.

In recent publications, it was highlighted that merely identifying the presence of an ethical situations is not enough (Halbesleben, Wheeler, \& Buckley, 2005). This is because once they have identified and made their own ethical decision, they are hesitant to voice it out. This is due to the belief that others hold the opposite opinion on the matter and that is the right one. In simplicity, they are in favour a 'perceived opinion' to which everyone are actually opposed to. The term pluralistic ignorance is applied at this instance (Halbesleben, Wheeler, \& Buckley, 2005). Going along this line, the moral reasoning judgement of an individual is constantly changing.

\subsection{Data collection}

\section{Methodology}

This research is qualitative in nature where mainly primary data is used. Journals were mainly used with a time frame of ten years. However, few of the articles can be considered outliers as they have been published nearly two decades ago. The chosen journal papers were then carefully analysed so that they can be divided into two main categories: ethics and accountability and ethics and education. Other than journals, references were also made to Code of Ethics for Accountants and Auditors of Islamic Financial Institutions (published by AAOIFI), Handbook of the Code of Ethics for Professional Accountants (published by International Federation of Accountants) and the Sarbanes - Oxley Act, 2002.

\subsection{Findings}

This part of the research will explain in detail how the objectives are achieved and the problem statement is laid out in a nutshell. The need for the accounting profession is omnipresent, be it traditional 
(conventional) or a Muslim. Just as the demand-supply theory works, where supply decreases when demand increases and vice versa, this profession is at times seen as very versatile. This is what this paper intends to investigate: is it very flexible in that even their morality is questioned?

Ethics in accounting practices is not a new issue but has been around for quite some time. The need for its discussion has arisen because of collapse of high profile organisations. One would remember Enron, Arthur Andersen or WorldCom. Though this may be the case, there is still a need to analyse what causes accountants to be involved in malpractice. Is it because they have no moral sensitivity or arising of conflict of interest or simply lack of ethical education at an earlier level of their accounting courses?

In the United States of America, the post-Enron period saw the cropping up of credibility crisis. Not everyone was willing to believe the financial statements they see. To instil some form of confidence in the users of financial statements, the Sarbanes Oxley Act (SOA) was passed in 2002. The main purpose of the act was 'to protect investors by improving the accuracy and reliability of corporate disclosures made pursuant to the securities laws, and for other purposes'.

With regards to the accounting profession, a board will be established, named the Public Company Accounting Oversight Board. They have the responsibility of overseeing the audit of public companies which follows the securities laws. This ensures the protection for investors and other stakeholders by providing them with an 'informative, accurate and independent audit reports'. Five out of their seven main duties touches on accounting firms: to register the public accounting firm, to conduct inspection on them, to conduct investigations and disciplinary actions on the firms, to perform other accounting functions which improve the qualities of audit services and to enforce compliance in relation to the audit reports and the obligations and liabilities of an accountant.

As to the members of the board, only two certified public accountants are allowed. In terms of inspecting the accounting firms, it is done annually for firms providing more than 100 audit reports while a minimum of three years is set for those issuing less than 100 reports. Other than these, the act highlights on accounting standards, corporate and criminal fraud accountability and white collar crime penalty enhancements. In internationalising the accountants' code of ethics, the International Federation of Accountants (IFAC) has issued a code, 'Code of Ethics for Professional Accountants'. The IFAC members consist of national accounting organisations and not individual professional accounting firms. Their mission is to ensure 'the worldwide development and enhancement of an accountancy profession with harmonised standards, able to provide services of consistently high quality in the public interest'. To be a member, an organisation has to at least follow a standard which is at par with the IFAC's own code. (Clements, Neill, \& Stovall, 2009).

The IFAC has established the International Ethics Standards Board for Accountants (IESBA) to develop and issues high quality ethical standards to be applicable throughout the world for professional purposes. In its published handbook, it has five sections relating to general ethical requirements. This includes integrity, objectivity, professional competency and due care, confidentiality and professional behaviour.

Under integrity, it has highlighted characteristics of being straightforward, honesty, fair dealings and truthfulness. An accountant also has to make professional judgements without any bias, conflict of interest or undue influence of others. In terms of competency, they have to maintain professional knowledge and skills and also diligent when applying any form of standards in their services. An accountant also has to preserve confidentiality by not disclosing it to outside firms and refrain from using it for personal benefits. When it comes to professional behaviour, the accountant is to avoid any action that could discredit the profession.

Due to the widely acknowledged fact that Islamic Finance is growing rapidly, it is customary that an Islamic Financial Institution (IFI) should possess some form of code of ethics. This is where AAOIFI has come up with its own set of code of ethics for accountants and auditors of IFIs.

In the Islamic Law (Shari'a), the accounting profession is a fardkifayah, which means that it is a collective religious duty. When some Muslims have performed it, it exempts others from doing it but if no one does it, then it becomes a sin to the entire community. In Islam, the act of recording and fair measurement has been repetitively mentioned in Al-Qur'an. As an example, verse 282 of Surah Al-Baqarah mentions the need to write down a debt for a fixed period and also the responsibility of the scribe. This goes to show that ethics or morality has been present in a Muslim trader some 1400 years ago and is not new.

This code of ethics set by AAOIFI is applicable to internal accountants and any other additional codes can only be followed if it is not in conflict with Shari'a rules and principles. The code was introduced as a means 'to help develop the accountants' ethical awareness of current practices and whether they are in line with Shari'a principle and to ensure the accuracy and reliability of accounting information presented in the financial statement.

Under this code, there are three sections: Shari'a foundations of accountant's ethics, principles of ethics of accountants and rules of ethical conduct for accountants. In the Shari'a, morality or ethics is a highly valued characteristic, which coincidentally falls in line with the Hadith: 'I have been sent to complement the most noble morals'. As part of the Shari'a framework of ethics, there are several features which are to be present in an accountant. These will be explained in the following paragraphs. 
Integrity is a value dear to Islam as one is required to be honest and truthful in their actions. Hence, to achieve this, an accountant has to well-versed in his discipline and able to exercise authority with high competency. This is as said in the Hadith: 'give back the trust to whoever has entrusted you with it'.

Another feature to be emphasised is vicegerency (khalifah) and accountability. These two features go hand-inhand with each other. Humans undertook the responsibility of being khalifah in this world, as is said in verse 72 of Surah Al-Ahzab:

"Truly, we did offer Al-Amanah (the trust or moral responsibility or honesty and all the duties which Allah has ordained) to the heavens and the earth, and the mountains, but they declined to bear it and were afraid of it (i.e. afraid of Allah's torment). But man bore it. Verily, he was unjust (to himself) and ignorant (of its results)."

Undertaking the responsibility meant that humans had to develop this world to fulfil his or her needs. Hence, they will be held accountable for how they develop it. In accounting perspective, one has to constantly improve their ethical standards, not because regulators will sniff out any unethical deeds but because Allah Subhanahu Wa Ta'ala will hold us responsible to it in the HereAfter.

Other salient features required in the Shari'a framework are sincerity, piety and righteousness.

Apart from this, if the ethical codes practiced by traditional accountants do not contravene with Shari'a principles, then this could be practiced as well. Some of features which can be applied are: trustworthiness, legitimacy, objectivity, competency and diligence.

Having gone through the ethics for an Islamic and traditional accountant, it can be seen that the code of ethics followed by both the traditional and Islamic accountants are similar in nature. Therefore, the cause for the rise of ethical issues or malpractice could not be due to lack of guidelines. Other reasons might be at play in the background which would need further investigations.

\section{Conclusion}

The ethical values of an accountant are of utmost importance for an organisation. This is because they are responsible towards preparing a comprehensive financial statement which indicates the performance of the organisation. Moreover, they are required to follow the ethical codes imposed by IFAC (for non-Islamic firms) and AAOIFI (mainly for IFIs).

After going through the required level of morality within an accountant, it seems incorrect to blame the regulators for not doing their job (i.e. not keeping an eye on organisations). From one side, it seems that the accountant themselves are to be blamed for the rise in number of accounting malpractices.

The principle of accountability is not followed whereby accountants feel that they can exploit any form of loopholes found. If they realise that their responsibility does not pertain to showing positive numbers only, then this unethical behaviours could be reduced as time goes by. If their ethical principle is controlled by those higher in the organisation, then one has to be steadfast in stressing that they realise their accountability to stakeholders and will not do as requested. All in all, the self-realisation of an ethical situation together with the actions taken is important when an ethical dilemma arises.

\section{Recommendations}

Looking at the problem of accounting malpractice, it is not an entirely new problem. People have been finding loopholes in every type of binding contracts just so they could gain some benefit for themselves. For accounting purposes, there are some recommendations which could be considered:

i. To develop an improvement in accountants, the ethical education in their courses would have to be strengthened further. This could be either in the form of open-discussion in class, reviewing latest case studies or other forms of productive discussions in class. An academician should not give their own opinion but rather engage the students so that they realise whish situations are ethical and requires proper solutions.

ii. Any accountants who have just graduated should not only look into how well-known the firm is or the salary scale. They should check how the organisation has fared so far, its credibility and how large of a customer base it is serving. A smaller customer base could probably mean that they have found their niche market and prefer to concentrate on them only or otherwise, having a large customer base is very risky because there are a lot of people to satisfy.

\section{IX. $\quad$ Future Research}

A lot can be improved if a future research is to be undertaken in this particular topic or even ethics of accountants in general. Firstly, a survey could be carried out to take into account the views of students and professional accountants (practitioners) regarding the ethical practices and issues in a Brunei context. Other than that, research could also be carried out on how the ethical education is integrated in the accounting courses. The outcomes of this research could be used to assess the level of ethical values deemed important in Brunei and also in the accounting profession specifically. 


\section{References}

[1]. Abdullah Yusuf Ali (1989). The Holy Qur'an: Text, Translation and Commentary

[2]. Clements, C., Neill, J. D., \& Stovall, O. S. (2009). An Analysis of International Accounting Codes of Conduct. Journal of Business Ethics, 173-183.

[3]. Code of Ethics for Accountants and Auditors of Islamic Financial Institutions, Accounting and Auditing Organisation for Islamic Financial Institution, 2010

[4]. Elias, R. Z., \& Farag, M. (2010). The relationship between accounting student's love of money and their ethical perception. Managerial Accounting Journal, 25(3), 269-281.

[5]. Abdullah Yusuf Ali (1989). The Holy Qur'an: Text, Translation and Commentary

[6]. Clements, C., Neill, J. D., \& Stovall, O. S. (2009). An Analysis of International Accounting Codes of Conduct. Journal of Business Ethics, 173-183.

[7]. Code of Ethics for Accountants and Auditors of Islamic Financial Institutions, Accounting and Auditing Organisation for Islamic Financial Institution, 2010

[8]. Elias, R. Z., \& Farag, M. (2010). The relationship between accounting student's love of money and their ethical perception. Managerial Accounting Journal, 25(3), 269-281.

[9]. Halbesleben, J. R., Wheeler, A. R., \& Buckley, R. M. (2005). Everybody else is doing it, so why can't we? Pluralistic Ignorance and Business Ethics Education. Journal of Business Ethics, 385-398.

[10]. Huss, H. F., \& Patterson, D. M. (1993). Ethics in Accounting: Values education without Indoctrination. Journal of Business Ethics, 235-243.

[11]. International Federation of Accountants. (2010). Handbook of the Code of Ethics for Professional Accountants. New York.

[12]. Jackling, B., Cooper, B. J., Leung, P., \& Dellaportas, S. (2007). Professional accounting bodies' perception of ethical issues, causes of ethical failure and ethics education. Managerial Auditing Journal, 22(9), 928-944.

[13]. Lewis, M. K. (2006). Accountability and Islam. Fourth International Conference on Accounting and Finance in Transition. Adelaide.

[14]. Sarbanes - Oxley Act 2002

[15]. Yunanda, R. A., \& Majid, N. b. (2011, December). The Contribution of Islamic Ethics towards Ethical Accounting Practices. Issues in Social and Environmental Accounting, 5(1), 124-137. 